\title{
KONSEP INTERAKSI EDUKATIF DALAM PENDIDIKAN ISLAM DALAM PERSPEKTIF AL-QUR'AN
}

\author{
Moch. Kalam Mollah \\ (Institut Teknologi Adhi Tama Surabaya)
}

\begin{abstract}
Abstrak:
Suatu kisah dapat dikatakan berkaitan dengan pendidikan apabila dalam proses interaksi yang ada pada kisah tersebut terdapat: tujuan pendidikan, pendidik, anak didik, materi dan metode. Oleh karena itu penulis mencoba mengkaji al-Qur'an dari kisah-kisah yang ada di dalamnya, dengan mengambil model interaksi pendidikan dalam perjalanan kisah orang tedahulu dalam al-Qur'an. Dari latar belakang diatas, maka muncul sebuah rumusan masalah dalam penelitian ini, yaitu bagaimanakah konsep interaksi edukatif dalam perspektif al-Qur'an dan implementasinya dalam pendidikan. Sumber data primer dalam penelitian ini adalah al-Qur'an tentang kisah Nabi Khidir dan Nabi Musa (Q.S. Al-Kahfi: 60-82), kemudian kisah Nabi Ibrahim dan Nabi Ismail (Q.S. Al-Shaffat: 102-107) dan yang terakhir adalah kisah Luqman (Q.S. Luqman: 12-19). Dilihat dari hasil penelitian menunjukkan bahwa konsep interaksi edukatif dalam al-Qur'an melalui kisah-kisahnya terdiri dari: 1) tujuan pendidikan: humanisasi, insan kamil dan akhlak mulia; 2) Pendidik: bijaksana, penuh kasih sayang, demokratis, mengenal murid dan memahami kejiwaaannya, berpengetahuan luas, memahami materi, sabar dan ikhlas; 3) Anak didik: Patuh, tabah, sabar, cita-cita yang kuat serta tidak putus asa dan bersungguh-sungguh, sopan santun, rendah hati dan hormat pada guru; 4) Materi: akidah, syari'ah dan akhlak; dan 5) Metode: dialogis, uswatun hasanah, demokratis, dan mauiz\}ah.
\end{abstract}

Kata Kunci : Pendidikan, Islam, Interaksi, Al-Quran. 


\begin{abstract}
:
A story is considered related to education if in the interaction process involves the following aspects: aims of education, educators, learners, material, and methods. In this research, the author examines stories inside the al-Qur'an, particularly which of educational interaction model within the people in the past. From the background above, this paper answers a research questions, what is the concept of educational interaction from the Qoranic perspective and its implementation in education world. The primary resources in this research is coming from the story of Ibrahim and Musa (Q.S. Al-Kahfi: 60-82), the story of Ibrahim dan Ismail (Q.S. Al-Shaffat: 102-107), and the story of Luqman (Q.S. Luqman: 12-19). The findings of this study show that the concept of educational interaction in in the al-Qur'an consists of 1) the aims of education: humanism, insan kamil, and highest endeavor; 2) the educators: wise, mercy, democratic, understanding students' psychological condition, knowledgeable, comprehending the materials, patient, and sincere; 3) the learners: obedient, determined, patient, strong motivation, never giving up, well mannered, humble, and respecting teachers; and 5) methods: dialogic, modelling, democratic, and advicing.
\end{abstract}

Keywords: Education, Islam, Interaction, al-Qur'an.

\title{
A. Pendahuluan
}

Kecenderungan manusia untuk berhubungan akan selalu melahirkan komunikasi dua arah melalui bahasa yang mengandung tindakan dan perbuatan. Karena ada aksi dan reaksi, maka dalam kehidupan semacam inilah interaksipun terjadi. Karena itu interaksi akan terjadi bila ada hubungan timbal balik antara dua orang atau lebih. ${ }^{1}$ Dengan demikian kegiatan hidup manusia akan selalu dibarengi dengan proses interaksi atau komunikasi, baik interaksi dengan alam lingkungan, interaksi dengan sesamanya, maupun interaksi dengan Tuhannya, baik itu disengaja maupun tidak disengaja.

Pendidikan merupakan sebagian dari fenomena interaksi kehidupan sosial manusia. Menurut K.J. Veeger pada hakekatnya kehidupan sosial itu terdiri dari jumlah aksi dan reaksi yang tidak terbilang banyaknya, baik antara perorangan maupun antara kelompok. Pihak-pihak yang terlibat

\footnotetext{
${ }^{1}$ Syaiful Bahri Djamarah, Guru dan Anak Didik dalam Interaksi Edukatif Suatu Pendekatan Teoritis Psikologis, (Jakarta: PT Rineka Cipta, 2005), 10.
} 
menyesuaikan diri dengan salah satu pola yang kolektif. Kesatuan yang berasal dari penyesuaian diri itu disebut kelompok atau masyarakat. Oleh karenannya pendidikan merupakan bagian dari interaksi sosial yang telah ada bersamaan dengan kehidupan manusia. ${ }^{2}$

Dari berbagai bentuk interaksi, ada istilah interaksi edukatif. Interaksi edukatif ini dalah interaksi yang berlangsung dalam suatu ikatan untuk tujuan pendidikan dan pengajaran. Oleh karena itu interaksi edukatif perlu dibedakan dari bentuk interaksi yang lain. Dalam arti yang lebih spesifik pada bidang pengajaran, dikenal adanya istilah interaksi belajar mengjar. Yaitu, interaksi yang dengan sadar meletakkan tujuan untuk mengubah tingkah lakudan perbuatan seseorang.

Dengan konsep diatas, memunculkan istilah guru disuatu pihak dan anak didik dilain pihak. Keduanya berada dalam interaksi edukatif dengan posisi tugas, dan tanggung jawab yang berbeda, namun bersama-sama mencapai tujuan. ${ }^{3}$

Sedangkan bicara dan membahas masalah interaksi edukatif, maka sudah banyak pakar pendidikan baik muslim maupun non muslim yang membahas konsep dan formula hal tersebut. Tapi kita sebagai orang yang beragama Islam, dimana Islam itu sendiri mempunyai Al-Qur'an sebagai sumber utama pedoman dan landasan hidup manusia secara umum dan hususnya umat Islam dalam semua aspeknya, baik aspek hukum, sosial, budaya, spiritual dan pendidikan. ${ }^{4}$

Maka, sudah sepantasnya dan seharusnya kalau kita mencoba dan berusaha untuk mengkaji, menganalisis dan mengeksplor kandungan AlQur'an yang berhubungan dengan ilmu pengetahuan dan pendidikan supaya bisa memberikan manfaat yang lebih besar terhadap kehidupan manusia hususnya dalam dunia pendidikan.

Dari sini dapat diketahui bahwa al-Qur'an adalah petunjuk utama bagi semua manusia hudan linnash demikian firman Allah SWT. Al-Qur'an merupakan petunjuk yang lurus bagi segenap umat manusia guna menggapai kebahagiaan kehidupan di dunia dan akhirat. Di dalamnya

\footnotetext{
2 Miftahul Huda, Interaksi Pendidikan 10 Cara Qur'an Mendidik Anak, (Malang: UIN Malang Press, 2008), 1.

${ }^{3}$ Syaiful Bahri Djamarah, Interaksi..., 11.

${ }^{4}$ Sufyan Tsauri, Mata Kuliah Pengembangan Kepribadian Islam (Bandung: Alfabeta, 2001), 22.
} 
termuat berbagai dasar aturan hukum yang mengatur segala aspek kehidupan umat manusia. Kandungan isi yang amat penting dan cukup lengkap dalam al-Qur'an diantaranya adalah ilmu pengetahuan dan pendidikan.

Pada hakikatnya isi dan makna al-Qur'an adalah paling lengkap dan sempurna. Tidak ada sesuatu apapun yang dialpakan dari al-Qur'an. Berpijak pada posisi tersebut maka dapat dipastikan bahwa misi atau makna al-Qur'an sangat mendalam, menyeluruh, meluas mencakup berbagai hal dan masalah baik yang ghoib maupun yang nyata. Memang tidak semuanya disebut secara eksplisit. Banyak hal dan masalah diungkap secara implisit. Dalam al-Qur'an aspek pengetahuan dan pendidikan tidak dijelaskan secara rinci. Karena al-Qur'an bukan buku ilmu pengetahuan atau ensiklopedia. Al-Qur'an hanya menggambarkan secara global (ijmal) dan tugas manusialah untuk menguraikannya, menemukan dan mempertajam spesifikasinya yang detail dari ilmu-ilmu tersebut. ${ }^{5}$

Hasan Langgulung merumuskan isi kandungan al-Qur'an dalam (1) aqidah, (2) akhlaq, (3) pemikiran/filsafat, (4) kisah orang terdahulu secara individu atau kelompok, (5) hukum syariah, baik terhadap khaliqnya atau terhadap sesama makhluk Mu'amalat.

Banyak kisah-kisah dalam Al Qur'an yang berkaitan erat dengan pendidikan karena merupakan sebuah interaksi yang mengandung unsurunsur pendidikan di dalamnya. Namun demikian, tidak semua interaksi dapat dikatakan proses interaksi edukatif, kecuali terlebih dahulu di perhatikan beberapa syarat dan faktor esensial dari proses interaksi edukatif tersebut.

Adapun interaksi dapat disebut interaksi edukatif, sebagaimana pandangan Winarno Surakhmad apabila memiliki beberapa unsur dasar; (1) bahan (materi) yang menjadi isi proses (2) tujuan yang jelas yang akan dicapai, (3) pelajar (anak didik) yang aktif mengalami (4) guru (pendidik) yang melaksanakan, (5) metode tertentu untuk mencapai tujuan (6) proses interaksi tersebut berlangsung dalam ikatan situasional (7) alat pendidikan.

Dengan demikian jelas bahwa suatu kisah dapat dikatakan berkaitan dengan pendidikan, apabila dalam proses interaksi yang ada pada kisah tersebut terdapat; tujuan pendidikan, pendidik, anak didik, metode, situasi

5 T.H. Thalhas, Fokus Isi dan Makna Al-Qur'an, (Jakarta: Galera Pase, 2008), cet. ke-1, h. 1-3 
pendidikan, materi atau bahan yang diberikan dalam proses pendidikan, dan alat pendidikan. ${ }^{6}$

Oleh karena itu penulis mencoba mengkaji Al-Qur'an dari kisahkisah yang ada di dalamnya dengan mengambil model interaksi pendidikan yang diterapkan dalam perjalan kisah didik-mendidik orang yang diceritakan dalam Al-Qur'an. Selain itu juga 'postulat' yang menjadi landasan kajiannya, yakni Al-Qur'an yang di dalamnya mempunyai kandungan kontekstual yang perlu dikaji rahasianya. Al-Qur'an bukan menjadi sesuatu yang pasif tetapi yang pasif adalah yang tidak menkajinya.

Interaksi pendidikan dalam al-Qur'an diformulasikan dari muatan materi yang diajarkan oleh masing-masing pelaku pendidikan dalam interaksinya dengan anak didiknya. Setidaknya, dari khazanah yang dipaparkan melalui contoh interaksi pendidikan yang dilakukan oleh para pendahulu kita dalam Al-Qur'an menjadi suri tauladan bagi pendidik dan anak didiknya itu sendiri. Karena pendidikan itu sendiri telah berusaha membantu hakikat manusia untuk meraih kedewasaannya, yakni menjadi manusia yang memiliki integritas emosi, intelek, dan perbuatan.

Relevasinya, landasan filosofis pendidikan anak yang digali dari sumber Islam, utamanya al-Qur'an menjadi konstribusi dalam interaksi pendidikan. Itu memberikan pencerahan melalui pemberdayaan spiritual peserta didik dan juga moralitasnya, baik personal maupun sosial. Yang lebih penting adalah membentuk anak didik menjadi insan kamil.

\section{B. Rumusan Masalah}

Berdasarkan latar belakang yang dikemukakan di atas maka permasalahan pokok yang akan di kaji dalam penelitian ini dapat dirumuskan sebagai berikut: Bagaimana konsep kisah-kisah interaksi edukatif dalam perspektif al-Qur'an dan implementasinya di dalam dunia pendidikan.

\section{Metode Penelitian}

Penelitian ini termasuk penelitian pustaka (literary research) yang merupakan telaah yang dilaksanakan untuk memecahkan suatu masalah

\footnotetext{
${ }^{6}$ Suismantoto, Pendidikan Akhlak dalam Al-Qur'an (Telaah Atas Kisah Nabi Musa dan Nabi Khidir as.),

http://uinsuka.info/ejurnal/index.php?option=com_content\&task=view\&id=75\&itemid=52
} 
yang pada dasarnya bertumpu pada penelaahan kritis dan mendalam terhadap bahan-bahan pustaka yang relevan. Menurut Iqbal, penelitian kepustakaan disebut juga library research, yaitu penelitian yang dilaksanakan dengan menggunakan literatur (kepustakaan), baik berupa buku, catatan, maupun laporan hasil penelitian dari peneliti terdahulu. ${ }^{7}$

Telaah pustaka semacam ini biasanya, dilakukan dengan cara mengumpulkan data dan informasi dengan bantuan dari berbagai sumber pustaka yang kemudian disajikan dengan cara baru atau untuk keperluan baru. Dalam hal ini bahan-bahan pustaka itu diperlukan sebagai sumber ide untuk menggali pemikiran atau gagasan baru sebagai bahan dasar untuk melakukan deduksi dari pengetahuan yang telah ada, sehingga kerangka teori baru dapat dikembangkan atau sebagai dasar pemecahan masalah. Dalam penelitian sumber pustaka yang digunakan antara lain terdiri dari alQur'an, kitab-kitab tafsir, buku kisah-kisah dalam al-Qur'an, buku pendidikan dan buku-buku yang ada korelasi dan relevansinya dengan penelitian ini.

Dalam penelitian ini pendekatan yang digunakan adalah deskriptif kualitatif, karena metode ini di kembangkan untuk mengkaji manusia dalam segala aspeknya seperti karya-karyanya, pendapat dan teori-teorinya. Termasuk dalam hal ini adalah firman Tuhan (Al-Qur'an) dan kisah-kisah dalam al-Qur'an untuk kasus-kasus terbatas (sifatnya kasuitis) namun mendalam dan menyeluruh.

Sumber data primer penelitian ini adalah Al-Qur'an tentang kisah Nabi Khidir dan Nabi Musa dalam surat al-Kahfi ayat 60-82, kemudian kisah Nabi Ibrahim dan Nabi Ismail yang terdapat dalam surat al-Shaffat ayat 102107 dan yang terakhir adalah kisah Luqman dalam surat Luqman ayat 1219. Sedangkan data sekunder diperoleh dari kitab-kitab tafsir Al-Qur'an dan buku-buku ilmiah, hususnya buku-buku pendidikan baik pendidikan Islam maupun pendidikan modern kontemporer serta buku-buku metode penelitian yang ada hubungan dan relevansinya dengan penulisan tesis ini.

Setelah data terkumpul maka proses selanjutnya adalah analisis data. Peneliti menggunakan metode induktif, yaitu cara berfikir yang berpijak dari fakta-fakta yang bersifat khusus, kemudian diteliti dan

\footnotetext{
${ }^{7}$ M. Iqbal Hasan, Pokok-Pokok Materi Metodologi Penelitian \& Aplikasinya, (Jakarta: Ghalia Indonesia,2002), 11.
} 
akhirnya ditemui pemecahan persoalan yang bersifat umum. ${ }^{8}$ Dalam penelitian ini, metode induktif digunakan untuk memperoleh gambaran yang utuh terhadap konsep interaksi edukatif yang terdapat pada kisahkisah dalam al-Qur'an. Dari beberapa sumber buku yang ada.

\section{Hasil Penelitian dan Pembahasan}

Ayat-ayat tentang interaksi dari Kisah Nabi Khidir dan Nabi Musa berisi perjalanan dengan tujuan untuk berguru pada seseorang yang memiliki ilmu yang tidak dimiliki olehnya. Secara umum, ayat-ayat tersebut berisi hal hal sebagai berikut: 1) Musa meminta kepada nabi Khidir untuk diperbolehkan berguru kepadanya; 2) Nabi Khidir menerima Musa dengan syarat; 3) Nabi Khidir memberikan ilmu yang secara logika tidak dapat di mengerti oleh Nabi Musa; 4) Nabi Khidir memutuskan untuk berpisah dengan Nabi Musa karena Nabi Musa tidak dapat menjalankan persyaratan Nabi Khidir; 5) Khidir menjelaskan takwil perilaku dari perjalanan yang selama ini dia lakukan.

Sedangkan, Kandungan ayat 102 sampai 107 surah al-Shaffat tersebut diatas secara garis besar sebagai berikut: 1) Allah memerintah Ibrahim untuk menyembelih ismail melalui mimpi; 2) Ibrahim mendialogkan mimpinya kepada Ismail dan meminta pendapatnya; 3) Ismail meminta Ibrahim untuk menjalankan perintah tersebut; 4) Peristiwa penyembelihan tidak terjadi, karena Allah mengganti dengan domba.

Pada bagian Surat Luqman yang diteliti, terdapat informasi sebagai berikut: 1) Luqman diberi hikmah oleh Allah; 2) Sikap hikmah Luqman dituinjukkan dengan menerapkan syukur; 3) Syukur luqman dilakukan dengan menasehati anak-anaknya dengan penuh kasih saying; dan 4) nasehat Luqman memuat materi pendidikan aqidah, syari'ah dan akhlak.

Pada kajian ini diperoleh gambaran awal bahwa sebagian kisahkisah pendidikan yang dinarasikan al-Qur'an, secara filosofis memuat unsur baku konsep pembentuk interaksi pendidikan, diantaranya adalah Tujuan pendidikan, Materi pendidikan, Pendidik dengan segala kompetensinya, Anak didik dengan etika akademiknya, Metode pendidikan dengan efektifitasnya.

Unsur dasar tersebut selama ini lazimnya diposisikan sebagai perpaduan antara faktor teoritis dan praktis yang memunculkan keyakinan

${ }^{8}$ Ibid., 28. 
akan kegiatan pendidikan terhadap manusia, oleh manusia, bertujuan mengembangkan hakekat kemanusiaan. Dari unsur pokok inilah maka kita akan membahas konsep interaksi edukatif secara terperinci yang ada pada kisah-kisah dalam al-Qur'an.

\section{Tujuan pendidikan dan Materi pendidikan}

Tujuan pendidikan dalam kisah-kisah al-Qur'an diformulasikan dari muatan materi yang diajarkan oleh masing-masing pelaku pendidikan dalam interaksinya dengan anak didiknya (Nabi Musa dan Nabi Khidir, nabi Ibrahim dan Ismail, dan yang terakhir Luqman Hakim). Pada intinya materi pendidikan dalam al-Qur'an dikelompokkan dalam tiga aspek yaitu akidah, syari'ah dan akhlak. Namun tidak semua kisah yang dikaji dalam tulisan ini memuat materi tersebut.

Pada pendidikan Khidir dan Musa materi, yang diberikan menekankan pada aspek akhlak dan keimanan. Sedangkan pendidikan yang dilakukan Ibrahim terhadap Ismail menekankan pada aspek aqidah dan syari'ah. Kemudian pendidikan yang dilakukan Luqman terhadap anaknya meliputi ketiga aspek tersebut yaitu, aqidah, syari'ah dan akhlak.

Interaksi pendidikan Khidir dan Musa Dalam kisah diatas diisyaratkan pada tiga materi penting yang diberikan oleh Khidir terhadap Musa, membocorkan perahu, membunuh anak, dan memperbaiki tembok rumah. Materi tersebut hanya merupakan sarana untuk mencapai tujuan, sedangkan inti materi pelajaran tersebut adalah akhlak dan akidah; pelajaran pertama, mengambil tindakan yang kecil bahayanya, untuk menghilangkan atau menolak bahaya yang lebih besar. Ini merupakan prinsip bagi pola tingkah laku muslim, sebagai dasar bagi akhlak mereka.

Pelajaran kedua, membunuh anak kecil. Ditinjau dari pandangan lahir, perbuatan tersebut merupakan perbuatan tercela dan dosa besar. Tapi bila ditelusuri lebih lanjut di dalamnya terdapat materi aqidah. Yaitu, seorang hendaknya rela akan takdir Allah, karena takdir Allah bagi seorang mukmin lebih baik dari apa yang disenanginya. Selain itu juga anak tersebut sengaja dibunuh agar orang tuanya terpelihara dari kesesatan dan kekejaman anak itu guna mempertahankan keimanan dan agama yang dianut oleh orang tua itu. 
Pelajaran ketiga, memperbaiki tembok rumah. hikmah yang terkandung dari pelajaran tersebut bahwa Allah akan memelihara orang yang shaleh beserta keturunannya (kedua anaknya dalam usia belianya dan masa lemahnya), walaupun mereka berjauhan. Pelajaran bagi umat Islam antar lain adalah bahwa kita harus menolong sesama manusia dengan ikhlas tanpa pamrih. Pada materi yang terakhir ini Khidir juga menenkankan materi akhlak kepada Musa.

Dan dari kasus Nabi Musa dan Khidir, pada pertemuan pertama antara Nabi Musa dan Khidir telah dipaparkan asal usul Musa yang bermula ketika sifat takabbur Musa muncul pada saat berpidato, sehingga ia mendapatkan teguran dari Allah. Latar belakang Musa ini kiranya menjadi bahan masukan bagi Nabi Khidir dalam merumuskan tujuan pendidikan, yakni pembinaan akhlak, dari kesombongan berbalik menjadi rendah hati, sabar dan tawadhu dalam situasi bagaimanapun. Sehingga dengan akhlak yang baik itu diharapkan dapat mempertebal keimanan kita kepada Allah Yang Maha Kuasa.

Dibalik materi penyembelihan Ibrahim terhadap Ismail terdapat materi pendidikan terkait yaitu aspek keimanan dan emosional (syari'ah). Perintah penyembelihan sangat berhubungan dengan hak hidup pribadi Ismail. Untuk melaksanakan perintah itu tidak saja melibatkan kesiapan emosional, tetapi juga kemantapan spiritual (iman). Pada tahapan ini, Ismail telah menunjukkan dedikasi yang tinggi dengan totalitas kesiapan emosionalnya untuk melaksanakan prosesi korban.

Inti dari pendidikan Ibrahim adalah humanisasi (memanusiakan manusia) dengan patuh kepada Allah. Pendidikan humanis ini berisi nilai-nilai keutamaan atau kebajikan yang dapat mengangkat kemuliaan manusia. Tujuan ini direalisasikan dengan membangun citra manusia yang taat kepada nilai-nlai kemanusiaan yang diperintahkan oleh Allah. Nilai kemanusiaan ditegakkan di atas sifat-sifat luhur budaya manusia yang terbebas dari sifat-sifat kebinatangan. Dengan pendidikan humanis ini diharapkan menjadi manusia yang sehat lahir batin. Pendidikan menjadikan anak mampu mengembangkan potensi dirinya dan mapu memilih dan mampu mempertanggungjawabkan apa yang telah 
dilakukan. Upaya inilah yang terlihat dalam model pendidikan Ibrahim terhadap Ismail.

Materi pendidikan yang diterapkan oleh Luqman hakim pada anaknya meliputi empat hal, antara lain: 1) Pendidikan keimanan (aqidah). Pendidikan inilah yang pertama kali dilakukan oleh Luqman kepada anaknya untuk menanamkan keyakinan bahwa Allah sebagai Dzat Yang Maha Esa yang harus disembah dan melarang perbuatan syirik. 2) Pendidikan syari'ah (ibadah). Ruang lingkup Syari'ah meliputi interaksi vertikal seorang hamba dengan Allah yang direalisasikan melalui ibadah Luqman mengajarkan shalat kepada anaknya, dan interaksi horizontal yang dilakukan dengan sesama manusia (muamalah), lalu memerintahkan kepada anaknya untuk membiasakan bersikap baik terhadap keluarga terdekat. 3) Pendidikan akhlak, pendidikan yang mula-mula dilakukan Luqman kepada anaknya adalah dengan memperkenalkan etika baik terhadap kedua orang tua. Kemudian berikutnya diajarkan padanya akhlak dalam konteks kemasyarakatan (sosial). Yang di dalamnya mencakup, pendidikan dakwah (amar ma'ruf nahi munkar) dan bersabar. Selain itu juga terdapat pendidikan etika yang lain, diantaranya adalah etika pergaulan (bertemu), berbicara dan berjalan.

Jika dilihat dalam kisah ini dapat diketahui bahwa tiga prinsip dasar Luqman Hakim kepada anaknya tersebut memenuhi target untuk membentuk insan kamil yang terdiri dari kesempurnaan aqidah, syari'ah dan akhlak (iman, Islam dan ihsan) yang dijadikan sebagai tujuan pendidikan Luqman.

Dalam pendidikan dan pengajaran, tujuan dapat diartikan sebagai suatu usaha untuk memberikan rumusan hasil yang diharapkan dari anak didik, setelah menyelesaikan/memperoleh pengalaman belajar. Winarno Surakhmad memberikan keterangan bahwa rumusan dan taraf pencapaian tujuan pengajaran adalah merupakan petunjuk praktis tentang sejauh manakah interaksi edukatif adalah harus dibawa untuk mencapai tujuan akhir.

Pada Undang-undang pendidikan RI No.20 tahun 2003, Bab II Pasal 3 tentang Sistem Pendidikan Nasional yang berbunyi: 
"Pendidikan nasional berfungsi menggambarkan kemampuan dan pembentukan watak serta peradaban bangsa yang bermanfaat dalam rangka mencerdaskan kehidupan bangsa, bertujuan untuk mengembangkan kemampuan peserta didik agar menjadi manusia yang beriman dan bertaqwa kepada Tuhan Yang Maha Esa, berakhlak mulia, sehat, berilmu, cakap, kreatif dan menjadi warga Negara yang demokratis serta bertanggung jawab".9

Dari rumusan tersebut dapat diberikan penjelasan secara rinci, bahwa prinsip tujuan Pendidikan Nasional adalah untuk membentuk manusia atau warga negara memiliki kriteria sebagai berikut: beriman dan bertaqwa kepada Tuhan Yang Maha Esa, berakhlak mulia, sehat, berilmu, cakap, kreatif dan menjadi warga Negara yang demokratis serta bertanggung jawab.

Disamping itu banyak juga disebut-sebut bahwa tujuan pendidikan itu pada hakikatnya memanusiakan manusia, atau mengantarkan anak didik dapat menemukan jati dirinya. Diri manusia adalah makhluk individu, makhluk sosial dan makhluk ciptaan Tuhan Yang Maha Esa. Dari tujuan pendidikan yang dimuculkan oleh kisahkisah interaksi edukatif perspektif al-Qur'an diatas yaitu, a) Pembinaan akhlak, b) Humanisasi, c) Pembentukan insan kamil. Maka tujuan pendidikan al-Qur'an tersebut dapat dihubungkan dengan tujuan pendidikan dan pengajaran yang terdapat dalam Undang-undang pendidikan dan pengajaran. Oleh karena itu dapat dikatakan bahwa sebenarnya tujuan pendidikan yang ada dalam al-Qur'an sudah diimplementasikan dalam pendidikan dan pembelaran pada saat sekarang ini.

Materi pendidikan merupakan bagian yang penting dalam proses belajar mengajar, yang menempati kedudukan yang menentukan keberhasilan pembelajaran yang berkaitan dengan ketercapaian tujuan pengajaran, serta menentukan kegiatan-kegiatan belajar mengajar. Pada pembahasan diatas telah diketahui bahwa inti dari materi pendidikan dalam al-Qur'an dikelompokkan dalam 3 aspek yaitu: akidah, syari'ah dan akhlak.

\footnotetext{
${ }^{9}$ Undang-undang RI No.20 Tahun 2003, Sistem Pendidikan Nasional, (Bandung: Citra Umbara, 2003), 6 .
} 
Tiga aspek tersebut pun masih dapat dijumpai dalam mata pelajaran yang masuk dalam struktur kurikulum di sekolah saat ini, baik mulai dari jenjang Taman Kanak-kanak (TK) hingga sampai pada jenjang Sekolah Menengah Atas (SMA) yang intinya terdiri dari: 1) pengembangan Moral dan Nilai-nilai Agama, 2) Pengembangan sosial dan emosional, 3) pengembangan kemampuan dasar. Dari sinilah dapat dikatakan bahwa sebenarnya inti materi pendidikan dalam al-Qur'an sudah diimplementasikan dalam pendidikan dan pembelajaran pada masa sekarang.

\section{Pendidik dengan segala kompetensinya}

Berbicara masalah interaksi belajar mengajar (edukatif), maka kita tidak bisa lepas dari hal "guru" atau "pendidik". Guru merupakan salah satu komponen dalam proses belajar mengajar, karena besarnya peranan tersebut maka seorang guru atau pendidik harus memiliki kompetensi-kompetensi. Sifat-sifat dasar (kompetensi) pendidik pada kisah-kisah dalam al-Qur'an ini meliputi bijaksana, penuh kasih sayang, demokratis, mengenal murid dan memahami kejiwaaannya, berpengetahuan luas, memahami materi, sabar dan ikhlas. Dalam perspektif pendidikan karakteristik ini dipahami dari eksplorasi pemaknaan terhadap interaksi pendidikan yang dilakukan Luqman, Ibrahim dan Khidir.

Dalam kisah ini dijelaskan bahwa kompetensi yang dimiliki oleh Luqman sebagai seorang pendidik, adalah bijaksana dan penuh kasih sayang. Kebijaksanaan Luqman ini disimpulkan dari cara pengajaran yang menekankan unsur kebijakan, karena ia telah diberi hikmah (kebijakan) oleh Allah. Dalam mendidik hendaknya menggunakan pendekatan yang bersifat penuh kasih sayang, hal ini dapat kita cermati dari seruan Luqman kepada anak-anaknya, yaitu “ $Y \bar{a}$ Bunayyă' (Wahai anak-anakku), seruan tersebut menyiratkan sebuah ungkapan yang penuh muatan kasih sayang, sentuhan kelembutan dalam mendidik anak-anaknya.

Pribadi Ibrahim sebagai pendidik menunjukkan sikap demokratis dalam mendidik anaknya. Demokratisasi pendidikan diterapkan dengan sasaran memberikan pilihan anak didik dengan 
penuh pertimbangan dan tanggung jawab. Untuk tugas berat inilah Ibrahim berusaha memahami kejiwaan Ismail, bagaimana kesanggupannya menjalankan perintah Allah tersebut. Ibrahim telah meminimalisisr sikap otoritatif (pemaksaan) dalam pendidikan, yaitu dengan memahami kesiapan mental Ismail. Hal itu terjadi karena Ibrahim berusaha memahami siapa dan bagaimana kesanggupan anak didik yang dihadapinya.

Dalam kisah Musa dijelaskan bahwa Khidir adalah sosok guru yang pemaaf tapi tegas. Hal itu bisa dilihat dari prilaku Musa yang telah berkali-kali melakukan kesalahan, tapi akhirnya Khidir tetap mau memaafkan, dan secara tegas langsung mengingatkan kesalahan Musa. Dari dua sifat pemaaf dan tegas itu dapat diketahui bahwa karakter Khidir adalah guru yang mengajar dengan penuh kasih sayang dan tanggung jawab.

Sejak pertemuan pertama Khidir telah mengenal jiwa muridnya itu yang di dalam al-Qur'an pun telah dijelaskan bahwa Nabi Musa itu mempunyai sikap jiwa yang lekas meluap atau sepontan. Bahkan guru itu menjelaskan lagi, sebagai sindiran halus atas sikap jiwa murid dengan perkataannya: bahwa sebenarnya Musa tidak akan sabar bila ikut bersamanya. Hal pokok lain yang harus dimiliki oleh guru, yaitu dia harus berpengetahuan luas dan memahami materi, hal ini juga nampaknya telah dimiliki oleh Khidir sebagaimana diketahui, ketika diceritakan kepada Musa bahwa ada seorang hamba Allah yang tinggal di tempat bertemunya dua laut, dia memiliki ilmu yang tidak dimiliki oleh Musa. Selain itu diharapkan bagi setiap guru memiliki sifat sabar dan ikhlas dalam mendidik seperti apa yang telah dilakukan Khidir kepada Musa.

Dalam proses interaksi belajar mengajar, guru adalah orang yang memberikan pelajaran dan siswa adalah orang yang menerima pelajaran. Dalam mentransfer pengetahuan kepada siswa diperlukan pengetahuan, kecakapan, atau keterampilan sebagai guru. Tanpa ini semua tidak mungkin proses interaksi belajar mengajar dapat berjalan secara kondusif. Disinilah kompetensi dalam arti kemampuan mutlak diperlukan guru dalam melaksanakannya sebagai pendidik dapat terlaksana dengan baik. Beranjak dari pengertian inilah kompetensi 
merupakan suatu hal yang tidak bisa dipisahkan dari kegiatan pendidikan dan pengajaran.

Dalam konsep interaksi edukatif perspektif al-Qur'an dijelaskan bahwa pendidik merupakan komponen dalam interaksi edukatif dan pendidik mempunyai peranan yang lebih. Oleh karena itu, seorang pendidik harus mempunyai kompetensi-kompetensi (sifat dasar pendidik), antara lain meliputi bijaksana, penuh kasih sayang, demokratis, mengenal murid dan memahami kejiwaaannya, berpengetahuan luas, memahami materi, sabar dan ikhlas.

Jika melihat dalam konsep pendidikan dan pembelajaran saat ini, diketahui bahwa banyak juga kajian tentang guru dan pendidik. Menurut Ditjen ketenagaan, Dirjen Dikdasmen dan Depdiknas kompetensi guru adalah suatu ukuran yang ditetapkan atau dipersyaratkan dalam bentuk penguasaan pengetahuan dan perilaku perbuatan agar berkelayakan untuk menduduki jabatan fungsional sesuai dengan bidang tugas, kualifikasi dan jenjang pendidikannya.

Berdasarkan Undang-undang Nomor 14 Tahun 2005 tentang Guru dan Dosen, pasal 10, dinyatakan bahwa kompetensi guru itu meliputi kompetensi paedagogik, kompetensi kepribadian, kompetensi sosial, dan kompetensi profesional yang diperoleh melalui pendidikan profesi. Dalam penjelasan undang-undang tersebut menyatakan bahwa yang dimaksud dengan kompetensi paedagogik adalah kemampuan mengelola pembelajaran peserta didik. Kompetensi kepribadian adalah kemampuan kepribadian yang mantap, berakhlak mulia, arif dan berwibawa serta menjadi teladan peserta didik. Kompetensi profesional adalah kemampuan penguasaan materi pelajaran yang luas dan mendalam. Kompetensi sosial adalah kemampuan guru untuk berkomunikasi dan berinteraksi secara efektif dan efisien dengan peserta didik, sesama guru, orang tua/wali peserta didik, dan masyarakat sekitar. ${ }^{10}$

Selain penjelasan diatas, kompetensi guru juga meliputi tentang adanya kemampuan guru dalam kegiatan pembelajaran. Selama pembelajaran berlangsung guru sendiri dituntut untuk mempunyai sifat

\footnotetext{
${ }^{10}$ Suwardi, Manajemen Pembelajaran Mencipta Guru Kreatif \& Berkompetensi, (Salatiga: STAIN salatiga Press, 2007), 4-6.
} 
yang demokratis ketika melaksanakan pembelajaran. Sikap demokratis itu sendiri pada intinya mengandung makna memperhatikan persamaan hak dan kewajiban semua orang. Dalam konsep pendidikan sekarang guru yang memiliki sifat ini pada umumnya dipandang sebagai guru yang baik dan ideal.

Dari semua penjelasan diatas, maka dapat ditarik benang merah bahwa kompetensi pendidik yang tersirat pada kisah-kisah interaksi edukatif dalam al-Qur'an sangat relevan dengan kompetensi guru (pendidik). Selanjutnya dapat diketahui bahwa profil pendidik dan kompetensinya menurut al-Qur'an sudah diimplementasikan dalam pendidikan. Hal itu dapat dilihat dari banyaknya kesamaan kompetensi yang dipaparkan dalam al-Qur'an dengan pembelajaran dan pendidikan saat ini.

\section{Anak didik dengan etika akademiknya}

Pada bagian tedahulu telah banyak dibicarakan tentang figur guru sebagai pokok yang mencerminkan pribadi yang mulia. Pembicaraan yang hanya difokuskan pada permasalahan guru adalah janggal. Karenanya akan dibicarakan juga kedudukan anak didik sebagai sosok yang masih memerlukan bimbingan dari guru dalam pendidikan dan pengajaran. Agar dapat memahami siapa anak didik itu sebenarnya, maka uraian pada bagian ini akan menjelaskan anak didik dan etika akademiknya yang ada dalam al-Qur'an melalui beberapa kisah dari Ismail, Musa dan Tharan. Etika anak didik dalam kisah-kisah ini meliputi: Patuh, tabah, sabar, punya kemauan atau cita-cita yang kuat serta tidak putus asa dan bersungguh-sungguh dalam mencari ilmu, sopan santun, rendah diri dan hormat pada guru.

Ibrahim telah meninggalkan sikap otoriter dan menetapkan sikap demokratis dalam mendidik Ismail. Implikasinya Ismail menunjukkan sikap patuh, tunduk dan tabah atas perintah penyembelihan itu. Ismail tidak menunjukkan rasa takut sama sekali atau berusaha untuk menyelamatkan diri dari maut hal itu terlihat dari dialog yang diucapkan Ismail terhadap ayahnya. Sebaliknya dengan bangga dan penuh rasa hormat dia mempersilahkan sang ayah untuk melaksanakan perintah tersebut. Hal ini terjadi karena dalam diri Ismail terdapat keyakinan akan keberhasilan dalam melampaui ujian itu. 
Pendidikan Luqman dilakukan dalam bentuk perintah dan larangan. Etika anak didik tidak menunjukkan reaksi inteaktif maupun dialogis. Juga tidak menunjukkan sikap menentang terhadap pendidik. Tidak ditemukannya reaksi jawaban dari anak Luqman pada ayat 12-19 tersebut menunjukkan sikap anak didik yang patuh.

Perjalanan jauh menuju pertemuan dua lautan dan dilanjutkan dengan perlawatan bersama gurunya yang ditempuh dengan melampui daratan dan lautan, memerlukan ketabahan, kesabaran, kemauan atau cita-cita yang kuat serta tidak putus asa dan bersungguh-sungguh dalam mencari ilmu. Dalam kisah ini ketabahan dan kesabaran Musa salah satunya ditunjukkan oleh kata huquba>. Selain sifat-sifat yang disebutkan diatas, Musa juga memiliki sifat sopan santun terhadap guru dan rendah diri kepadanya yang tercermin dari permohonan penejelasan pemahaman tanpa memaksa. Dalam kisah ini pun menunjukkan reaksi interaktif antara Khidir dan Musa secara dialogis atas prilaku yang bertentangan dengan pengetahuannya.

Meskipun dalam kisah ini terdapat sedikit sifat pertentangan antara guru dan murid, tapi sebagai murid yang baik, Musa berani mengakui kesalahan dan segera meminta maaf atas kesalahan yang telah diperbuat, dengan penuh hormat dan rendah diri kepada guru. Dari uraian ini dapat diambil garis merah bahwa nilai pendidikan yang terkandung dalan kisah Musa agar peserta didik memiliki motivasi yang tinggi dan memiliki sikap sopan santun dan rendah diri.

Murid adalah salah satu komponen dalam pengajaran, disamping faktor guru, tujuan dan metode pembelajaran. Sebagai salah satu komponen maka dapat dikatakan bahwa murid adalah komponen yang terpenting diantara komponen lainnya. Pada dasarnya "ia" adalah unsur penentu dalam proses belajar mengajar. Tanpa adanya murid, sesungguhnya tidak akan terjadi proses pengajaran. Sebabnya ialah karena muridlah yang membutuhkan pengajaran dan bukan guru. Guru hanya berusaha memenuhi kebutuhan yang ada pada murid. Muridlah yang belajar. Tanpa adanya murid guru tidak akan mengjar. Sehingga murid adalah komponen terpenting dalam hubungan proses belajar mengajar ini. 
Karena hal itulah, maka al-Qur'an sebagai suatu kitab pedoman yang kebenarannya akan tetap terjaga dan juga merupakan sebuah pedoman yang berisi tentang semua hal yang ada juga mengemukakan tentang peserta didik. Menurut kisah-kisah yang tedapat al-Qur'an yang telah di bahas diatas, dapat dikatakan bahwa etika peserta didik yang harus dimiliki antara lain: Patuh, tabah, sabar, punya kemauan atau citacita yang kuat serta tidak putus asa dan bersungguh-sungguh dalam mencari ilmu, sopan santun, rendah diri dan hormat pada guru.

Tugas utama seorang anak didik adalah belajar, makna dari kata belajar adalah proses. Yang dalam hal ini suatu proses dimana seorang pendidik mentransformasikan pengetahuan. Sehingga makna belajar lebih ditekankan kepada prosesnya. Oleh karena itu, dari semua suku kata diatas yaitu tentang makna belajar, apabila dipadukan akan mendapatkan suatu definisi yaitu suatu peraturan normative baik tertulis maupun tidak tertulis bagi peserta didik dalam proses belajar dan bagaimana peserta didik mampu mempertanggung jawabkan semua yang terjadi dalam proses belajar. Dalam hal ini bisanya dituangkan dalam kode etik dan sifatnya etika terhadap pendidik.

Sejalan dengan itu dapat diketahui bahwa etika peserta didik dalam al-Qur'an khususnya yang terdapat dalam hasil kisah-kisah kajian diatas, harus dimilki oleh tiap peserta didik pada saat ini. Dari beberapa penjelasakan diatas, sudah dapat dilihat bahwa sebenarnya etika peserta didik dalam al-Qur'an sudah diimplementasikan dan relevan dengan pendidikan serta pembelajaran pada saat ini yaitu yang tertera dalam kode etik murid.

\section{Metode pendidikan dengan efektifitasnya}

Metode adalah cara atau siasat, yang dipergunakan dalam pengajaran. Sebagai strategi metode ikut memperlancar ke arah pencapaian tujuan pembelajaran. Peranan metode ini akan nyata jika guru memilih metode yang sesuai dengan tingkat kemampuan yang hendak dicapai oleh tujuan pembelajaran. Ada beberapa temuantemuan metode yang terdapat dalam kisah ini. Metode-metode tersebut ialah dengan cara mauizah ditemukan pada diri Luqman. Pada Ibrahim 
ditemukan metode dialogis-demokratis. Sedangkan Khidir menggunakan metode dialogis-uswah hasanah.

Dalam ekspedisinya dengan Nabi Musa, Musa berkali-kali bertanya kepadanya tentang pelajaran yang belum berhak dipelajarinya secara tergesa-gesa. Namun Nabi Khidir menegurnya dengan tenang bahwa muridnya ini tidak akan bersabar. Dari peristiwa tersebut terlihat bahwa metode yang digunakan oleh Nabi Khidir adalah membiasakan diri agar tidak tergesa-gesa dalam menghukumi sesuatu, berdasarkan pada ilmu yang dimilikinya. Dalam hal ini terlihat bahwa interaksi pendidikan Khidir kepada Musa terdapat aspek dialogis yang terjadi.

Disamping itu terlihat juga Nabi Khidir menegakkan disiplin dengan berusaha untuk menerangkan apa yang disepakatinya sebelum pemberangkatan. Dari hal ini terlihat bahwa Nabi Khidir menggunakan metode uswah hasanah atau memberi suri tauladan yang baik, yaitu selalu berdisiplin, menepati janji, dan sadar akan tujuan.

Metode dialogis demokratis terlihat pada model pendidikan Ibrahim terhadap Ismail. Dialog dipahami sebagai upaya untuk membuka jalur informasi antara pendidik dan anak didik. Dalam hal ini, ibrahim mendialogkan mimpinya tentang penyembelihan Ismail. Dialog dilakukan untuk mengetahui persepsi psikologis Ismail tentang permasalahan yang dihadapi. Disinilah Ibrahim mengenalkan konsep ketauhidan, dengan menekankan perintah penyembelihan itu datang dari Allah.

Metode yang dilakukan Luqman terlihat pada metode mauizah yang berfungsi untuk membangkitkan semangat spiritual untuk beriman kepada Allah. Tidak ditemukan reaksi menentang yang dilakukan anak didik atas nasehat Luqman. Hal ini berarti pendidikan melalui mauizah berjalan secara monolog (searah) dari pendidik kepada anak didik dan tidak memberi kesempatan kepada anak didik untuk menginterfensi nasehat tersebut. Tampaknya metode mauizah ini efektif untuk menanamkan nasehat-nasehat yang bersifat dogmatif-doktriner.

Metode pendidikan berarti cara-cara yang dipakai oleh guru agar tujuan pendidikan dapat dipakai secara efektif dan efisien. Pemilihan metode pendidikan sangat ditentukan oleh bentuk pendidikannya. Minimal ada tiga bentuk pendidikan yang telah berlangsung dalam 
proses pendidikan, antara lain pendidikan otoriter, pendidikan liberal, dan pendidikan demokratis. Bentuk pendidikan ini menempetkan pendidik dan peserta didik dalam posisi seimbang. Dari ketiga bentuk tersebut, pendidik akan memilih metode apa yang sesuai dengan bentuk pendidikan yang diterapkannya.

Dalam proses pembelajaran, pendidik dalam memilih metode pembelajaran sebaiknya memperhatikan hal-hal sebagai berikut: tujuan pendidikan; kemampuan pendidik; kebutuhan peserta didik; materi pelajaran.

Dalam penjelasan terdahulu telah diketahui bahwa temuantemuan metode yang terdapat dalam kisah ini meliputi mauizah yang ditemukan pada diri Luqman. Pada Ibrahim ditemukan metode dialogisdemokratis. Sedangkan Khidir menggunakan metode dialogis-uswah hasanah. Bila dilihat lebih jauh lagi sebenarnya metode-metode diatas telah banyak dijumpai pada pembelajaran sekarang ini. Seperti metode mauiz\}ah yang sekarang lebih dikenal dengan metode ceramah. Menurut Nahlawi metode ceramah ini sangat cocok sekali untuk digunakan untuk menanamkan rasa iman. Metode ini pun sering digunakan karena ceramah mudah dilakukan dan dapat menghasilkan sejumlah materi pelajaran dengan peserta didik yang banyak pula.

Untuk merealisasikan metode dialog dan demokratis dapat digunakan teknik-teknik sebagai berikut; teknik tanya jawab, teknik diskusi, teknik bantah-bantahan, teknik brainstorming (sumbang saran). Teknik dialog dan demokratis ini pun sering dijumpai dalam pembelajaran karena teknik ini dianggap mampu mengaktifkan siswa dalam kegiatan pembelajaran.

Sedangkan metode uswatun hasanah dapat dijumpai dalam pembelajaran dan merupakan metode yang penting sebab teknik ini digunakan dengan cara memberikan contoh teladan yang baik, yang tidak hanya diberikan dalam kelas tapi dalam kegiatan sehari-hari oleh karena itu, setiap guru harus melaksanakan metode uswah ini dalam kehidupan sehari-harinya.

Selain memilih metode seorang guru juga harus pandai kapan ia harus menggunakan satu metode saja dan kapan ia harus menggunakan multi metode, seperti dalam uraian kisah diatas Luqman dalam 
pendidikannya dia Cuma menggunakan satu metode saja sedangkan Khidir dan Ibrahim menggunakan dua metode sekaligus.

Akhirnya dari uraian diatas tersebut membukikan bahwa sesungguhnya metode yang ada dalam al-Qur'an tersebut telah diimplementasikan dalam pembelajaran.

\section{E. Penutup}

Setelah dilihat keseluruhan aspek interaksi edukatif yang terdapat pada kisah-kisah dalam al-Qur'an tersebut berikut dengan penjelasannya, maka dapat diketahui bahwa pola interaksi edukatif dalam al-Qur'an tersebut terdiri dari metode searah dan metode interaktif. Metode searah menggambarkan sentralisasi kegiatan pendidikan peda pendidik. Anak didik diposisikan sebagai obyek pendidikan yang harus diisi dengan materi pendidikan. Metode searah ini memiliki relevansi dengan materi pengajaran yang bersifat dogmatis seperti masalah keimanan dan ibadah. Sikap tegas pendidik disertai tanggung jawab atas profesi pendidikan mampu mengkondisikan sikap patuh bagi anak didik.

Pola interaktif menggambarkan interaksi pendidikan berjalan dua arah antara pendidik dan anak didik. Pola ini menjadikan dialog sebagai sarana komunikasi untuk penyampaian pesan pendidikan. Efektifitas pola komunikasi ini mengkondisikan pendidikan pada sifat demokratis, humanis karena memberdayakan potensi anak didik secara rasional dan emosional.

Berawal dari latar belakang permasalahan kemudian diarahkan dengan perspektif teori sehingga mengantarkan pada pemaparan data dan melahirkan analissis, pada akhirnya tema besar kisah-kisah interaksi edukatif dalam perspektif al-Qur'an ini menghasilkan kesimpulan.

Diketahui bahwa penjelasan konsep interaksi edukatif yang disajikan al-Qur'an melaui kisah-kisahnya adalah sebagai berikut:

Tujuan pendidikan. Dari ketiga kisah di atas kesimpulan tujuan pendidikan yang diharapkan meliputi: a) Pembinaan akhlak, b) Humanisasi, c) Pembentukan Insan kamil.

Materi pendidikan. Pada intinya materi pendidikan dalam al-Qur'an dikelompokkan dalam tiga aspek yaitu akidah, syari'ah dan akhlak begitu juga dalam penelitian ini aspek materi yang terkandung didalamnya juga mencakup tiga materi tersebut. 
Pendidik. Kompetensi pendidik yang terdapat dalam kisah-kisah ini meliputi bijaksana, penuh kasih sayang, demokratis, mengenal murid dan memahami kejiwaaannya, berpengetahuan luas, memahami materi, sabar dan ikhlas.

Anak didik. Selain guru etika anak didik pun harus diperhatikan yang meliputi: Patuh, tabah, sabar, punya kemauan atau cita-cita yang kuat serta tidak putus asa dan bersungguh-sungguh dalam mencari ilmu, sopan santun, rendah diri dan hormat pada guru.

Metode pendidikan. Dalam kisah ini diketahui bahwa metode yang menonjol yang digunakan pendidik untuk menyampaikan pesan pada anak didknya adalah: Luqman dengan mauiz\}ah, pada Ibrahim ditemukan metode dialogis-demokratis. Sedangkan Khidir menggunakan metode dialogisuswah hasanah.

Terdapat dua pola komunikasi yang disajikan dalam penelitian ini, yaitu: pola komunikasi searah dan pola komunikasi interaktif.

Konsep interaksi edukatif perspektif al-Qur'an di atas, sebenarnya mulai dari sajian tujuan pembelajaran, materi pendidikan, kompetensi pendidik, etika anak didik dan metodenya semuanya sudah diimplementasikan pada pendidikan dan pembelajaran pada masa sekarang ini.

\section{F. Daftar Pustaka}

Djamarah, Syaiful Bahri, Guru dan Anak Didik dalam Interaksi Edukatif Suatu Pendekatan Teoritis Psikologis, Jakarta: PT Rineka Cipta, 2005. Huda, Miftahul, Interaksi Pendidikan 10 Cara Qur'an Mendidik Anak, Malang: UIN Malang Press, 2008.

Tsauri, Sufyan, Mata Kuliah Pengembangan Kepribadian Islam, Bandung: Alfabeta, 2001.

Thalhas, T.H., Fokus Isi dan Makna Al-Qur'an, Jakarta: Galera Pase, 2008.

Suismantoto, Pendidikan Akhlak dalam Al-Qur'an (Telaah Atas Kisah Nabi Musa dan Nabi Khidir as.),

http://uinsuka.info/ejurnal/index.php?option=com content\&task= view\&id=75\&itemid $=52$

Hasan, M. Iqbal, Pokok-Pokok Materi Metodologi Penelitian \& Aplikasinya, Jakarta: Ghalia Indonesia, 2002.

Undang-undang RI No.20 Tahun 2003, Sistem Pendidikan Nasional, Bandung: Citra Umbara, 2003. 
Moch. Kalam Mollah

Suwardi, Manajemen Pembelajaran Mencipta Guru Kreatif \& Berkompetensi, Salatiga: STAIN salatiga Press, 2007.

Jurnal Pendidikan Agama Islam

Volume 3 Nomor 2 November 2015

ISSN: 2089-1946

Hal. 256 - 256 